\title{
Evaluation of Anti-HBsAg Titres among the High-Risk Population of A Tertiary Care Hospital, Tamil Nadu, India
}

\author{
P. Sneka ${ }^{1 *}(\mathbb{D})$, V. Sangamithra ${ }^{1}$, D.C. Vidya ${ }^{2}$ and K.P. Hamsadwani ${ }^{1}$ (D) \\ ${ }^{1}$ Department of Microbiology, Bhaarath Medical College \& Hospital, Selaiyur, Chennai - 600073 , India. \\ ${ }^{2}$ Department of Community Medicine, Bhaarath Medical College \& Hospital, Selaiyur, Chennai - 600073 , India.
}

\begin{abstract}
Health care workers (HCW) are a high-risk population for Hepatitis B infection. Hepatitis B vaccine which is $\mathbf{9 5 \%}$ effective confers long-term protection and anti-HBs titre is a marker for protective immune response. Our objective was to assess the status of hepatitis $B$ vaccination and to evaluate the anti-HBsAg titres among health care workers in a tertiary care hospital, Tamil Nadu. It was an observational study conducted among $\mathbf{6 1 0}$ Health care workers in a tertiary care teaching hospital from June to December 2018 after obtaining clearance from IEC. Workers were assessed for their HBV vaccination status and for their anti-HBsAg titre after getting informed consent. The antibody titres were measured using CLIA (chemiluminescent Immunoassay) supplied by Abbott diagnostics. The data was entered and analyzed using a Microsoft Excel sheet. In our study, $80.5 \%$ were fully vaccinated, $18.5 \%$ of them were defaulters which comprised the HCW with 2 doses and 1 dose of vaccine and $0.9 \%$ were not vaccinated. In the fully vaccinated group, $37 \%$ showed Anti HBs titres of $10-100 \mathrm{mlU} / \mathrm{ml}, 59.2 \%$ showed the titre of $>100 \mathrm{mIU} / \mathrm{ml}$ and $3.6 \%$ did not show the protective antibody titre $(<10 \mathrm{mIU} / \mathrm{ml})$. The $3.6 \%$ who did not show protective antibody titre were given the booster dose of vaccine. Among those who received a booster dose, $61.1 \%$ responded with the titre of $10-100 \mathrm{mIU} / \mathrm{ml}$ and $22.2 \%$ responded with the titre of $>100 \mathrm{mlU} / \mathrm{ml}$ and $16.6 \%$ did not respond even with the booster dose. In the defaulters $86.7 \%$ had titres $<10 \mathrm{mlU} / \mathrm{ml}, 9.7 \%$ had titres of $10 \mathrm{mlU} / \mathrm{ml}$ and $3.6 \%$ had titres $>10$ $\mathrm{mIU} / \mathrm{ml}$. In the non vaccinated group all had titres $<10 \mathrm{mlU} / \mathrm{ml}$. The present study emphasizes the importance of screening of anti-HBsAg titres to be made mandatory for all the health care workers along with HBV Vaccination.
\end{abstract}

Keywords: Hepatitis B, Health care workers, HBsAg titre, Vaccination

\footnotetext{
*Correspondence: drsneka87@gmail.com

(Received: April 17, 2021; accepted: January 5, 2022)

Citation: Sneka P, Sangamithra V, Vidya DC, Hamsadwani KP. Evaluation of Anti-HBsAg Titres among the High-Risk Population of A Tertiary Care Hospital, Tamil Nadu, India. J Pure App/ Microbiol. 2022;16(1):384-388. doi: 10.22207/JPAM.16.1.32

(C) The Author(s) 2022. Open Access. This article is distributed under the terms of the Creative Commons Attribution 4.0 International License which permits unrestricted use, sharing, distribution, and reproduction in any medium, provided you give appropriate credit to the original author(s) and the source, provide a link to the Creative Commons license, and indicate if changes were made.
} 


\section{INTRODUCTION}

Hepatitis B is a viral infection that attains greater significance because of its high risk of transmission. HBV infection occurs in a large proportion of the world's population. ${ }^{1}$ It is a leading cause of Chronic hepatic diseases ultimately ending in hepatocellular carcinoma. ${ }^{2}$ Health care professionals are a high-risk group for Hepatitis $B$ and are advised vaccination against hepatitis B. ${ }^{3}$ According to WHO, " $5.9 \%$ of HCWs are each year exposed to blood-borne HBV infections corresponding to about $66,000 \mathrm{HBV}$ infections in HCWs worldwide". ${ }^{4}$ Data from various studies conducted in different parts of India revealed only $<60 \%$ Health care community received Complete $\mathrm{HBV}$ vaccination. This is eventually who are at high risk of acquiring the infection. ${ }^{5,6}$

$\mathrm{HBV}$ infection can be prevented by timely vaccination at $0,1,6$ Months and the efficacy of the vaccine is around $95 \%$. Hepatitis B vaccine confers long-term protection, and anti-HBs titre is a marker for protective immune response. ${ }^{7}$ It is very essential to look for Anti-HBsAg titres since their levels decrease over time. ${ }^{8}$

Though guidelines suggest three doses of vaccine is effective in producing protective antibody levels, there has been always a debate regarding the need for an additional booster dose. ${ }^{9}$ The evaluation of immune status following vaccination is important in susceptible populations as there is always a group who remain as nonresponders to the hepatitis $B$ vaccine and continue to be at risk for acquiring the infection. ${ }^{10}$ Hepatitis $B$ vaccine confers long-term protection against both clinical illness and its sequelae. An easily detectable anti-hepatitis B surface antigen (Anti$\mathrm{HBs}$ ) level is a marker for protection. ${ }^{11,12}$. So it is essential to screen the health care workers for hepatitis $B$ vaccination and to check the titre of anti-HBs which serves as the marker of protective status.

\section{Objectives}

1. To Check for Hepatitis B vaccination status among the high-risk group.

2. To evaluate the anti-HBsAg titres in completely vaccinated and defaulters.

3. To check the efficacy of a booster dose in the non-responders to the Primary vaccine schedule of HBV.

\section{MATERIALS AND METHODS}

A total of 610 Health care workers working in a tertiary care teaching hospital which includes 270 doctors, 150 Nurses, 90 Technicians and 100 Housekeeping staff were assessed for their HBV vaccination status and for their antiHBsAg titre. The antibody titres were measured using CLIA (chemiluminescent Immunoassay) supplied by Abbott diagnostics.

\section{Ethics}

The study was conducted after obtaining clearance from the ethical committee.

\section{Consent}

Informed consent was obtained from the study group before enrolling in the study.

\section{Inclusion criteria}

All the health care workers irrespective of age, sex were included in the study

\section{Exclusion criteria}

People other than health care workers were excluded from the study.

\section{RESULTS}

The distribution of the study group based on the profession is given in Fig. 1.

$491 \mathrm{HCW}$ out of 610 (80.5\%) had completed all the three doses of the vaccine as recommended.

The distribution of HCW with all three doses of vaccine is given in Table 1.

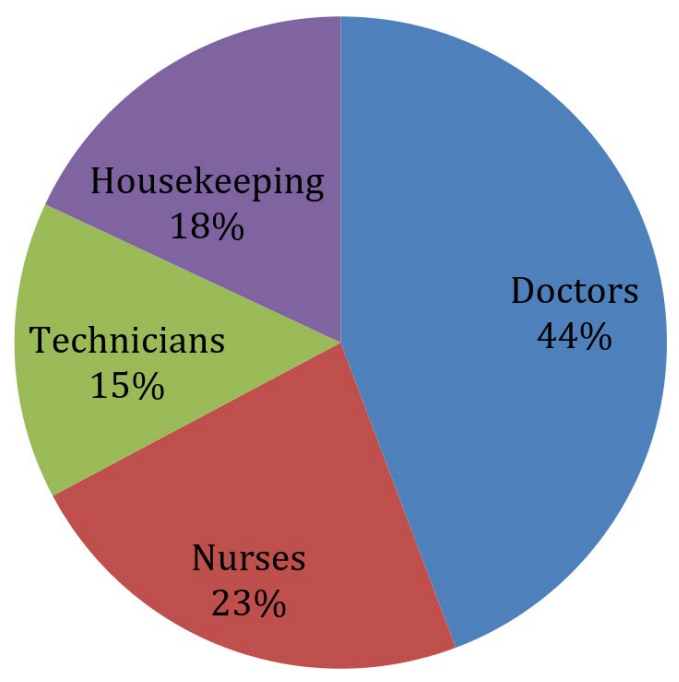

Fig. 1. Distribution of Health care Workers based on the work profile. 
The study groups with two doses of vaccine is given in Table 2.

The distribution of the study group with one dose of vaccine is given in Table 3.

6 of the $610 \mathrm{HCW}$ in the study gave history of no vaccination. All of the 6 were housekeeping staff.

Based on the above data that was obtained the HCW were divided into three groups, the fully vaccinated group, the defaulters and the non-vaccinated group. The distribution of the

Table 1. Study groups with three doses of the vaccine

\begin{tabular}{lccc}
\hline No. & Category & $\begin{array}{r}\text { Total } \\
(\mathrm{n}=491)\end{array}$ & $\begin{array}{c}\text { Percentage (\%) } \\
(80.5 \%)\end{array}$ \\
\hline 1. & Doctors & 258 & $95.5 \%$ \\
2. & Nurses & 122 & $87.1 \%$ \\
3. & Technicians & 65 & $72.2 \%$ \\
4. & Housekeeping & 46 & $46 \%$ \\
& staff & & \\
\hline
\end{tabular}

Table 2. Study group with two doses of the vaccine

\begin{tabular}{lccc}
\hline No. & Category & $\begin{array}{r}\text { Total } \\
(\mathrm{n}=87)\end{array}$ & $\begin{array}{c}\text { Percentage (\%) } \\
(14.2 \%)\end{array}$ \\
\hline 1. & Doctors & 12 & $13.7 \%$ \\
2. & Nurses & 11 & $12.6 \%$ \\
3. & Technicians & 24 & $27.5 \%$ \\
4. & Housekeeping & 40 & $45.9 \%$ \\
& staff & & \\
\hline
\end{tabular}

study group based on vaccination status is shown in Fig. 2.

Of the 491 (80.5\%) HCW who were fully vaccinated , $18(3.6 \%)$ had titres $<10 \mathrm{mlU} / \mathrm{mL}, 182$ (37\%) had titres of $11-100 \mathrm{mIU} / \mathrm{mL}, 291(59.2 \%$ ) had titres $>100 \mathrm{mIU} / \mathrm{mL}$. Out of the 113 defaulters (18.5\%) (2 doses 88 ,one dose 25) 04 (3.5\%) had titres of $>10 \mathrm{mIU} / \mathrm{mL}, 11(9.7 \%)$ had titre of $10 \mathrm{mIU} /$ $\mathrm{mL}$ and $98(86.7 \%)$ had titres $<10 \mathrm{mIU} / \mathrm{mL}$. Booster dose were given for the 18 fully vaccinated $\mathrm{HCW}$ with titres $<10 \mathrm{mIU} / \mathrm{mL}$. 15/18 (83.3\%) responded to the booster of which $11(61.1 \%)$ had titres $>10$ $\mathrm{mIU} / \mathrm{mL}, 4(22.2 \%)$ had titres of $>100 \mathrm{mlU} / \mathrm{mL}$ and $3(16.6 \%)$ were non responders. Of the $6(0.9 \%)$ non vaccinated $\mathrm{HCW}$ all had titre $<10 \mathrm{mIU} / \mathrm{mL}$.

\section{DISCUSSION}

Comparing the data obtained from all the three groups it was clear that compliance was higher with doctors followed by nurses and technicians. Compliance was least observed with housekeeping staff which is similar to the study

Table 3. Study group with one doses of the vaccine

\begin{tabular}{lccc}
\hline No. & Category & $\begin{array}{r}\text { Total } \\
(\mathrm{n}=26)\end{array}$ & $\begin{array}{c}\text { Percentage (\%) } \\
(4.2 \%)\end{array}$ \\
\hline 1. & Doctors & 0 & $0 \%$ \\
2. & Nurses & 7 & $26.9 \%$ \\
3. & Technicians & 1 & $3.8 \%$ \\
4. & Housekeeping & 18 & $69.2 \%$ \\
& staff & & \\
\hline
\end{tabular}

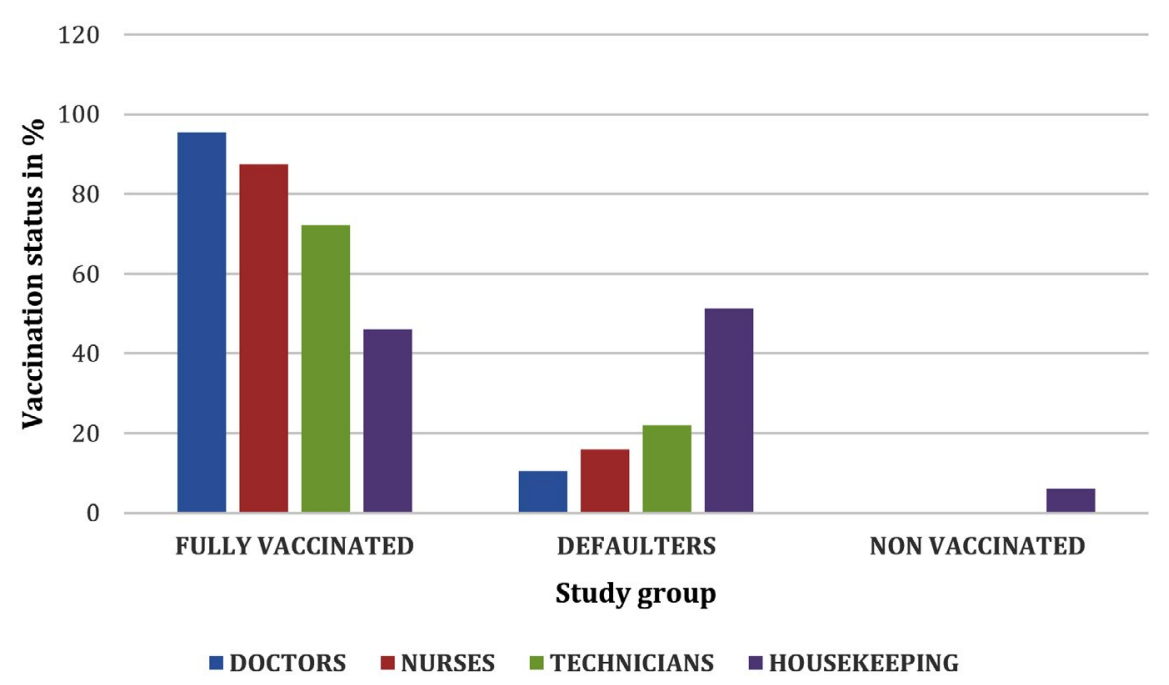

Fig. 2. Study groups based on vaccination status. 
done by Vishal Batral et al., Iftekhar et al. and Syed moayed alavian et al. ${ }^{13-14}$ Housekeeping staff are the major risk group for $\mathrm{HBV}$ because these are the population involved in handling bio-medical waste. Awareness programmes should be conducted highlighting the importance of HBV vaccination in Health care setup.

We found in the fully vaccinated group $59.2 \%$ had titres of $>100 \mathrm{mlU} / \mathrm{mL}, 37 \%$ had titres of $10-100 \mathrm{mIU} / \mathrm{mL}$. It was also found even in the fully vaccinated group $3.6 \%$ were non-responders with titres of $<10 \mathrm{mIU} / \mathrm{mL}$. In a study done by Alekhya et al., ${ }^{15}$ it was found $6 \%$ were found nonresponders in the completely vaccinated group of $\mathrm{HCW}$. In the present study, a booster dose to the non-responders to the routine ( $0,1,6$ Months) dose and $83.3 \%$ responded with protective titres of $\geq 10 \mathrm{mIU} / \mathrm{mL}$. However, $16.6 \%$ were permanent non-responders.

It is clearly evident that routine screening of antibody titre is to be done among vaccinated HCW to identify the non-responders and implement policies that can suggest for providing additional booster doses if required and also take necessary precautionary measures to ensure their safety in the workplace.

Also in contrast to the belief that the partially vaccinated group does not develop protective titres, it was found in our study that $13.2 \%$ has titres $\geq 10 \mathrm{mlU} / \mathrm{mL}$.

\section{CONCLUSION}

The present study emphasizes the importance of screening of anti-HBsAg titres to be made mandatory for all the health care workers along with HBV Vaccination. It also implies the need for health education to the HCW on HBV to ensure compliance with the vaccine.

\section{ACKNOWLEDGMENTS}

None.

\section{CONFLICT OF INTEREST}

The authors declare that there is no conflict of interest.

\section{AUTHORS' CONTRIBUTION}

All authors listed have made a substantial, direct and intellectual contribution to the work and approved it for publication.

\section{FUNDING}

None.

\section{DATA AVAILABILITY}

The datasets generated during and/or analysed during the current study are available from the corresponding author on reasonable request.

\section{ETHICS STATEMENT}

The study was approved by the Institutional Ethics Committee, Bhaarath Medical College and Hospital, Chennai, Tamil Nadu, India. (BIEC-45-20).

\section{INFORMED CONSENT}

Written informed consent was obtained from the participants before enrolling in the study.

\section{REFERENCES}

1. Kao JH, Chen DS. Global control of hepatitis B virus infection. Lancet Infect Dis. 2002;2(7):395-403. doi: 10.1016/S1473-3099(02)00315-8

2. Hollinger FB, Liang TJ, et al.: Hepatitis B virus. In Fields Virology. 4th edition. Edited by: Knipe DM, Howley PM, Griffin DE, Lamb RA, Martin MA, Roizman B. LippincottRaven Publishers, Philadelphia, PA; 2001:2971-3036.

3. Mast EE, Margolis HS, Fiore AE, et al. A Comprehensive immunization strategy to eliminate transmission of hepatitis B virus infection in the United States: Recommendations of the advisory committee on Immunization Practices (ACIP) part 1: Immunization of infants, children and adolescents. MMWR Recomm Rep 2005;54:1-31

4. Pruss-Ustun A, Rapiti E, Hutin Y. Estimation of the global burden of disease attributable to contaminated sharps injuries among health-care workers. Am J Ind Med. 2005;48(6):482-490. doi: 10.1002/ajim.20230

5. Pati NT, Sethi A, Agrawal K, et al. Low level of awareness, vaccine coverage, and the need for booster among health care workers in tertiary care hospitals in India. J Gastroenterol Hepatol. 2008;23(11):17101715. doi: 10.1111/j.1440-1746.2008.05483.x

6. Duseja A, Arora L, Masih B, et al. Hepatitis B and $C$ Virus-prevalence and prevention in health care workers. Trop Gastroenterol. 2002;23(3):125-126. PMID: 12693154

7. Ciorlia LAS, Zanetla DMT. Hepatitis B in health care workers: Prevalence, vaccination and relation to occupational factors. Braz J Infect Dis. 2005;9(5):384389. doi: 10.1590/S1413-86702005000500005

8. Sjogren $\mathrm{MH}$. Prevention of hepatitis $B$ in non responders to initial hepatitis $B$ virus vaccination. $A m$ J Med 2005;118(Suppl 10A):34-39. doi: 10.1016/j. amjmed.2005.07.012

9. Hepatitis B virus: A Comprehensive Strategy for Eliminating Transmission in the United States through 
Universal Childhood Vaccination. Recommendations of the Immunization Practices Advisory Committee (ACIP). MMWR Recomm Rep. 1991;40:1- 25.

10. Chaudhari CN, Bhagat MR, Shah T, Misra RN. Antibody to hepatitis $B$ surface antigen in vaccinated health care workers. Med J Armed Forces India. 2008;64(4):329332. doi: 10.1016/S0377-1237(08)80013-5

11. Mast E, Mahoney F, Kane, M, Margolis H. Hepatitis B vaccine. In: Plotkin SA, Orenstein WA (Eds). Vaccines (4th ed). Philadelphia: Saunders, 2004, 299-337.

12. Hutin $Y$, Hauri $A$, Chiarello $L$, et al. Best infection control practices for intradermal, subcutaneous, and intramuscular needle injections. Bulletin of the World
Health Organization. 2003;81(7):491-500. PMID: 12973641

13. Alavian S-M, Izadi M, Zare A-A, et al. Survey of the level of anti-HBs antibody titer in vaccinated Iranian general dentists. Spec Care Dentist. 2008;28(6):265-270. doi: 10.1111/j.1754-4505.2008.00052.x

14. Batra V, Goswami A, Dadhich S, Kothari D, Bhargava N. Hepatitis B immunization in healthcare workers. Ann Gastroenterol. 2015;28(2):276-280. PMID: 25830669

15. Jayalakshmi L, Alekhya P, Sasikala G. AntiHBs Titers in Health Care Persons of Clinical Laboratory. IOSR Journal of Dental and Medical Sciences. 2017;16(10):54-57. 